\title{
Fertility Development in the Baltic Countries Since 1990: a Transformation in the Context of Long-term Trends
}

\author{
KALEV KATUS, Ph.D., Professor and Director $\dagger$ \\ ALLAN PUUR, Ph.D., Senior Researcher \\ LUULE SAKKEUS, Ph.D., Senior Researcher \\ ASTA PÕLDMA, M.A., Researcher \\ Estonian Interuniversity Population Research Centre, Tallinn, Estonia
}

\begin{abstract}
The article addresses the transformation of fertility patterns in the Baltic countries since the turn of the 1990s, in the context of long-term trends. The purpose of the study is to compare the change in fertility level, parity distribution, timing of childbearing, and the connection between marriage and childbearing in Estonia, Latvia and Lithuania, and analyze the position of the Baltic countries in a broader European perspective. Our results indicate a salient role of tempo effects in the sharp decline of period fertility measures that occurred in the region in the 1990s. Tempo-adjusted measures indicate moderately low fertility levels of 1.6-1.7 children per woman in the region. In the recent years, fertility levels have been rising in all three countries with recuperation being more vigorous in Estonia and less so in Lithuania. Estonia and Latvia also appear more advanced in terms of the spread of childbearing among cohabiting couples, with the proportion of non-marital births comparable to Scandinavian countries. The article discusses the factors underlying the observed similarities and dissimilarities in fertility patterns, pointing to the plausible demographic path dependence.
\end{abstract}

Keywords: fertility, family formation, societal transition, comparative analysis; Baltic countries.

\section{Introduction}

The years since the turn of the 1990s have witnessed a dynamic change of fertility and family patterns in Europe. In many respects, the centre of gravity of the recent transformation relates to the region that was sealed off by the Cold War. Following the disappearance of the iron curtain", the region has witnessed a change over a range of interrelated processes, including a shift from population increase to depopulation, rapid decline of fertility, a drop in marriage rates, accelerated postponement of relatively early childbearing and family formation, pluralisation of living arrangements 
etc (Council of Europe 2006; Eurostat 2008). These shifts in demographic behaviour have occurred and progressed in the context of an extensive societal transformation which involves conversion of the economic system towards market economy, (re) institution of democratic political system and (re)creation of civic society, with an array of repercussions in the lives of individuals.

Over the past decade, a growing volume of research has addressed the transformation of fertility patterns in Central and Eastern Europe. A majority of these works have focused on national level, but by the same token, there is a number of studies that viewed fertility and family development in comparative perspective (e.g. Dorbritz and Philipov 2003; Kucera et al. 2000; Macura and MacDonald 2003; Sobotka 2004). Applying the cohort perspective, these studies are complemented by a comprehensive account of childbearing trends in low-fertility countries, initiated by Gerard Calot and Tomas Frejka (Frejka and Sardon 2004). Along the same lines, demographers have paid attention to the spread and characteristics of low fertility regime in Europe since the early 1990s (Golini 1998; Lesthaeghe and Williams 1999; Kohler, Billari and Ortega 2002; Freijka and Sobotka 2008).

The present article aims to contribute to the referred body of research by analysing recent fertility development in the three Baltic countries - Estonia, Latvia and Lithuania. Although there are several studies published on individual countries (Katus 2000; Katus, Puur and Sakkeus 2000; Katus, Puur and Põldma 2002; Stankuniene 2000, Stankuniene et al. 2000; Stankuniene and Jasilioniene 2008; Zvidrinsh, Greitans and Ezera 1998; Zvidrinsh 2000), comparative research focusing on contemporary fertility patterns in the Baltic region appears relatively scarce. The moment for undertaking such comparison seems appropriate as more than a decade and a half has passed since the onset of the changes around 1990. Although the cycle of transformation is yet far from complete, there is evidence from all three countries that the decline of fertility that used to dominate the scene for nearly a decade has come to an end, making room for an emerging recuperation in period fertility rates.

Readers interested in fertility development in the Baltic region over the long run are advised to consult the relevant publications. The dynamics of fertility transition in Europe has been comprehensively studied within the framework of the Princeton Fertility Project. Aside the final monograph of the project by Coale and Watkins (1986) province-level information pertaining to the territories of modern Estonia, Latvia and Lithuania can be found in the volume on the Russian Empire by Coale, Anderson and Härm (1979). Also later studies, applying the methodology of the Princeton project, have addressed the course of fertility transition comparatively in Estonia, Latvia and Lithuania, and in a wider Baltoscandian perspective, involving a comparison with Denmark, Finland, Norway and Sweden (Katus 1994; 1997).

Returning to the present study, the article sets to explore the main similarities and dissimilarities in recent fertility developments between Estonia, Latvia and Lithuania. 
To facilitate the task, two approaches are applied in conjunction. On the one hand, the recent changes are placed in the context of earlier trends of post-transitional fertility, stretching back to the 1960s. On the other hand, the developments in the Baltic countries are viewed against the background of trends observed in major regions of Europe over the same period. This double comparison over time and space allows to extend the analytical perspective and examine how the position of the Baltic countries has evolved in terms of fertility patterns. A further value of such perspective arises from its capacity to disclose the links between the past and present in demographic development and envisage the likely course of the future trends.

The study draws on published and unpublished fertility statistics, from national sources as well as from the demographic collection of the European Population Committee. Structurally, the article consists of four sections. Following the introduction, the second section briefly explains the data sources employed. The third section presents the main analytical findings, covering the level of fertility, parity distribution, timing of childbearing, including the influence of fertility postponement on observed fertility rates and the connection between marriage and childbearing. The concluding section includes a summary and a discussion of the findings.

\section{Data sources}

The present section discusses briefly the issues related to population and fertility statistics which are still different compared to many other European countries. The geopolitical rearrangements ensuing from the Second World War introduced a severe discontinuity into statistical systems in the Baltic region. In all three countries, statistical offices were dissolved and replaced by subordinate units, controlled completely by the central authorities in Moscow. A general account of the methodology and organisation of population statistics in the Baltic region during that period is published elsewhere (e.g. Anderson et al. 1994; Katus et al. 1997; Katus and Puur 2003; 2006). With respect to vital statistics, the moulding of national systems to the Soviet standard did not compromise the completeness of registration. With respect to Estonia, this assertion was confirmed by a recent study focused on the quality of archival birth records of the early postwar decades (Katus, Puur and Põldma 2004), and by all odds, a similar conclusion can be extended to Latvia.

In analysing the demographic development in the Baltic region, including fertility, two specific problems deserve particular attention. The first of these problems relates to data availability. Although the rules have varied during the fifty years, censorship prevented the open publication of any meaningful information and the publication of general statistical yearbooks was resumed only towards the late 1960s. More information was included in demographic yearbooks for official use, issued in Latvia and Lithuania on an annual basis since 1960s (TsSU Latvii 1965-1989; TsSU Litvõ 
1966-1990) and irregularly in Estonia (TsSU Estonii 1975; 1978; 1982; 1987). However, for a demographic analysis, including the present article for instance, even these classified publications prove insufficient, and for the purpose of research, the use of unpublished statistical material is inevitable. For the present study, only the unpublished primary tabulations were capable of providing the number of births, disaggregated by single-year age group of mother and parity. In a more general wording, everyone interested in the Baltic demography should take notice that for the postwar period up to 1991, until the ultimate fall of the restrictions on data availability, one obtains the most complete information from unpublished statistical tabulations, preserved either in the central archives or in statistical offices. ${ }^{1}$

The second specificity of the Baltic region relates to the indicators that can be found in published as well as unpublished sources. In this regard, the general recommendation is to recalculate all the indicators in order to avoid inconsistency related to numerator as well as denominator in demographic rates. This recommendation is also extended to the period following 1991. To address these problems, in Estonia systematic efforts were launched in the framework of the national data harmonisation programme initiated by the Estonian Demographic Association. Thanks to the programme not all recalculation/ data harmonisation tasks need to be addressed by research teams individually on an ad hoc basis. The core of the referred programme consisted of the recalculation of age structures, i.e. the denominator for any demographic rates. Currently, the recalculation has been accomplished for the period 1950-2000. The harmonised estimates are assembled in the Estonian Population Databank and are extensively used for demographic analysis, including the present article.

As regards comparative fertility data on other countries, the article draws on the European Population Committee's demographic collection (Council of Europe 2006). To allow for a concise comparison of large amounts of information, the data are summarised as unweighted arithmetic means for four distinctive geographical regions of Europe - Northern, Western, Southern and Central Europe. The definition of these regions applied in the article follows a delineation, which has been often used in demographic studies to outline the patterns of fertility and family development in Europe (e.g. Coleman 1996; van de Kaa 1999). In the article, northern Europe represents Denmark, Finland, Norway and Sweden. Western Europe is used to denote Ireland, Austria, Belgium, France, Germany (West Germany prior to reunification), Ireland, Luxembourg, the Netherlands, Switzerland and the United Kingdom. Southern Europe encompasses Greece, Italy, Portugal and Spain. Central Europe refers to Bulgaria, the Czech Republic, East Germany (until reunification), Hungary, Poland, the Slovak Republic and Slovenia. The CIS and Balkan countries were left out of the comparison primarily for the reason of limited data availability.

\footnotetext{
${ }^{1}$ A complete inventory of unpublished vital statistics tabulations produced for Estonia, Latvia and Lithuania in 1945-1989 is available from Katus and Puur (2003). The summary of the input data, used in the calculation of fertility measures, is presented in the appendix table at the end of the article.
} 


\section{Comparative analysis of fertility development in the Baltic countries}

In the following section, the analysis of fertility development in the three Baltic countries addresses four major dimensions of the process - level, order-specific fertility, timing of childbearing and age pattern of fertility, and marital status of mother at childbearing. Each subsection examines the recent changes that have occurred in the Baltic region, in the context of longer trends and concurrent developments in other parts of Europe.

\section{Dynamics of fertility level}

In the context of sharp fertility decline in the 1990s all over Central and Eastern Europe, the same change is usually seen as characteristic of the Baltic countries. Indeed, the period total fertility rate has decreased considerably, and compared to several other CEE countries, the downward trend has been even more pronounced, accounting for nearly one child per woman within a decade (Figure 1). Comparing the experience of the three Baltic countries to each other, at the beginning the change progressed at a somewhat slower pace and appeared less sharp in Lithuania. However, towards the end of the 1990s the country caught up with its two neighbours, and a couple of years after the turn of the century period TFR in the three countries reached a convergence point.

As noted above, the (sharply) decreasing fertility represents a characteristic feature of Central and Eastern Europe, and the general explanations proposed support the inclusion of the Baltic countries in that broader region as well. With a certain degree of simplification, two major hypotheses have been developed to explain the fertility decrease that occurred in Central and Eastern Europe in the 1990s. The first hypothesis ascribes the change primarily to various (economic) difficulties faced by the populations of the CEE region after the breakdown of the socialist (communist) regime (e.g. Kohler and Kohler 1999; Rychtarchikova 2000; Steshenko 2000; Philipov 2002). The second hypothesis relates fertility decrease to the second demographic transition that is assumed to have started in the 1990s in the CEE region (Zakharov 2000; Lesthaeghe and Surkyn 2002; Vishnevski 2006). In both general frameworks, a (sharp) fertility decrease is expected in the Baltic countries, consistent with the trends prevailing all over the Central and Eastern Europe. When applying a longer time perspective and taking a closer look, a more nuanced and to some extent even contrasting impression of fertility development in the Baltic countries emerges.

The right-hand panel of Figure 1 is placing fertility development in the Baltic countries into European context, by comparing it to the trends in major regions of the continent. Over the longer run, the post-transitional fertility in the Baltic region (in the article the data are presented from 1960 onwards) has been characterised by a noticeable stability 
of the level, stretching up to the end of the 1980s. On the other hand, in comparative perspective precisely this stability has implied the changing position of the Baltic countries vis--vis other regions of Europe.

In the early 1960s (like in the 1950s), the fertility in the Baltic countries appeared much lower than in any other region. Particularly with respect to Northern and Western Europe, the well-known reason underlying this dissimilarity is the baby boom that followed WWII and persisted up to the late 1960s (Festy 1984; Calot and Sardon 1997). Also, the countries which had not experienced under-replacement fertility before the war featured (still) relatively high fertility during that period. The Baltic region, on the other hand, experienced no baby boom after the war and represented the only area of low (and under-replacement) fertility in Europe until the late 1960s. In terms of period TFRs, the Baltic fertility levels were up to 0.75 lower, compared to Western and Southern Europe. Moreover, in the 1950s Estonia and Latvia had probably the lowest fertility in the world, with total fertility rates at 1.7-1.8 children per woman.
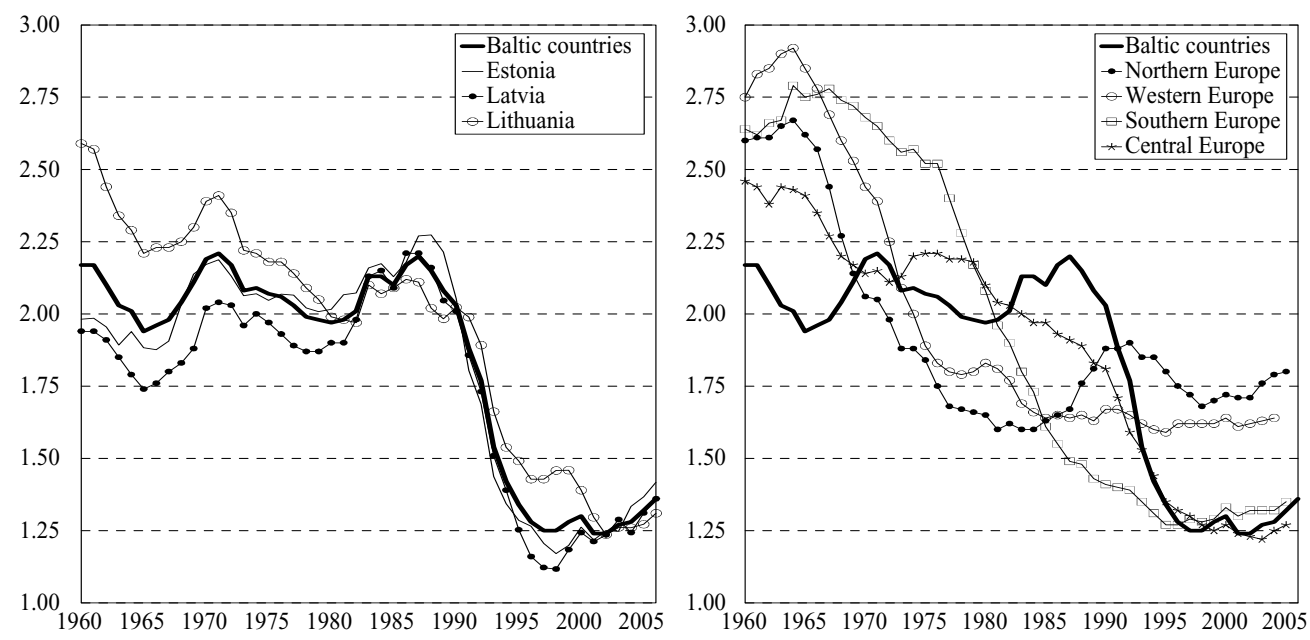

Figure 1. Total fertility rate 1960-2005.

In the late 1960s a new stage - later conceptualised as the second demographic transition - began and shaped the demographic trends in the following decades in Western and Northern, but also in Southern Europe (Lesthaeghe and van de Kaa 1986; van de Kaa 1987). Among multiple changes in demographic processes, brought together in the concept of the SDT, fertility decrease was substantial in most, if not all countries. Unlike the general trend in these major regions of Europe, however, in Estonia and Latvia period fertility increased rather than decreased in the late 1960s, setting the trend for the Baltic region as a whole. Over the longer run, the fertility in the Baltic region kept close to the replacement level for the following twenty years, being somewhat higher compared to the immediate postwar decades. As an outcome of these developments, 
in the end of the 1980s fertility level in the Baltic region appeared higher than in any major region of the continent - in 1985-1990, the average TFR accounted for 2.12 in the Baltic countries. In other words, somewhat paradoxically, the relative stability of fertility during four decades moved the Baltic region from the lowest to the highest position, compared to major regions of Europe.

Turning back to recent developments, the trend observed until the late 1980s implies that in the Baltic countries fertility decline started from a very high level, judging by the European standards of that period. About a decade and a half after the onset of fertility decline, period fertility in the Baltic countries is lower compared to Western and particularly Northern Europe, however, it has not dropped below the levels observed typically in Southern and Central Europe. In such view, it is the remarkably high starting point in the turn of the 1990s rather than the subsequent level that has strengthened the fertility decline and explains why the scale of the decline in the Baltic countries exceeds that in the other regions of Europe.

Another conspicuous change that has occurred during the recent years relates to a difference in fertility levels between the Baltic countries themselves. For about a centurylong period of fertility transition, Lithuanian fertility has been systematically higher compared to that in Estonia and Latvia. Understandably, the referred difference stems from the fact that the timing of demographic transition in Lithuania lagged behind its northern neighbours for about 15-20 years. The tail end of the Lithuanian fertility transition is captured on the left-hand panel of Figure 1, and as one can notice, it was only in the 1980s when fertility levels in the Baltic countries converged. However, the convergence seems to be temporary, and unlike in the past, concurrently the Baltic region is witnessing a reverse ordering of countries by fertility level, with Lithuania featuring the lowest and Estonia having the highest level in the Baltic region. According to the most recent statistics reported by statistical offices, in 2007 the period TFR accounted for 1.35 in Lithuania, 1.41 in Latvia and 1.64 in Estonia.

\section{Order-specific fertility}

Order-specific fertility, drawing on parity distribution of births, relates closely to total fertility as each major change in the latter is accompanied by corresponding shifts in parity distribution, or actually vice versa, to put it correctly from the viewpoint of causal logic. In this subsection, total fertility rate is disaggregated between three birth orders (first births, second births, and third births combined with all higher-order births). For all these parities, two sets of graphs are presented, comparing the trends in order-specific total fertility rates in the Baltic countries between themselves and placing the Baltic region in a broader European context (Figure 2). This way, the analysis of order-specific fertility contributes to the understanding of changes in fertility level, discussed in the previous section. 
The data reveal that the trends in first-order total fertility rate in the three Baltic countries have been rather similar. Concerning the 1990 s, first-order total fertility also indicates a somewhat later start and slower progression of fertility decline in Lithuania. In the preceding decades, the similarity between the countries is perhaps even more pronouced as the lines are clustered closely together. Among others, the limited differentiation of the first-order TFR could be explained by the nature of the process/measure itself - indeed, first births tend to show higher stability since in virtually all settings a strong majority of people are having at least one child. In the Baltic countries after the turn of the 1990s, however, the validity of such an argument seems unsupported because of a rather extensive decrease in TFR1. As revealed by the figure, the first-order total fertility rate dropped from about 1.0 close to which it had stayed for a long period (even above that limit for several years), to the level of ca 0.6 . From the demographic point of view, neither of these levels cannot be assumed to be realistic (or even possible) at the cohort level. The reasons forcing the period fertility beyond this range are discussed in the following sections.

Over the longer run, the stability of first-order total fertility rate in the Baltic countries up to the 1990s resulted in the repositioning of the region vis-vis other parts of Europe, as it was observed for all parities combined in the previous chapter. In earlier decades, the Baltic first-order fertility was comparable to other parts of Europe, but from the 1970s onwards one region after another dropped below the Baltic level and by the end of the decade the Baltic first-order fertility emerged as the highest compared to major regions of the continent during the 1980s. Starting from the very high level, the decline in TFR 1 experienced by the Baltic countries in the early 1990s was sharper than in any region of Europe. The figure also shows that against the high rate in the late $1980 \mathrm{~s}$, the decline brought the Baltic countries closer to the situation observed in other parts of the continent.

Turning to second-order fertility, the decline has followed a largely similar path in the 1990s. However, in earlier decades the trajectory of TFR2 appears noticeably less stable and less homogeneous in the Baltic region. In Estonia and Latvia, with large fluctuations, the TFR2 showed an upward trend from the early 1960s up to the late 1980s (Figure 2). The data reveal fluctuations also in Lithuania, but unlike its two neighbours, the second-order fertility shows no increase over the referred period.

Coming back to Estonia and Latvia, understandably the rise in TFR2 contributed to the increase in total fertility rate, particularly in the late 1960s. It is important to note that namely this rise, carried by the native population in urban areas (in Estonia, probably also in Latvia), brought fertility back to replacement and completed an approximately forty-year period when fertility was persistently below that level. The increase in the 1980s was driven by different factors, including the rise in fertility among foreign origin population and a change in the age-pattern of childbearing. The decline of the secondorder total fertility rate was particularly intensive and exceeded the decrease observed for the first parity - compared to the end of the 1980s, TFR2 decreased about two times. 

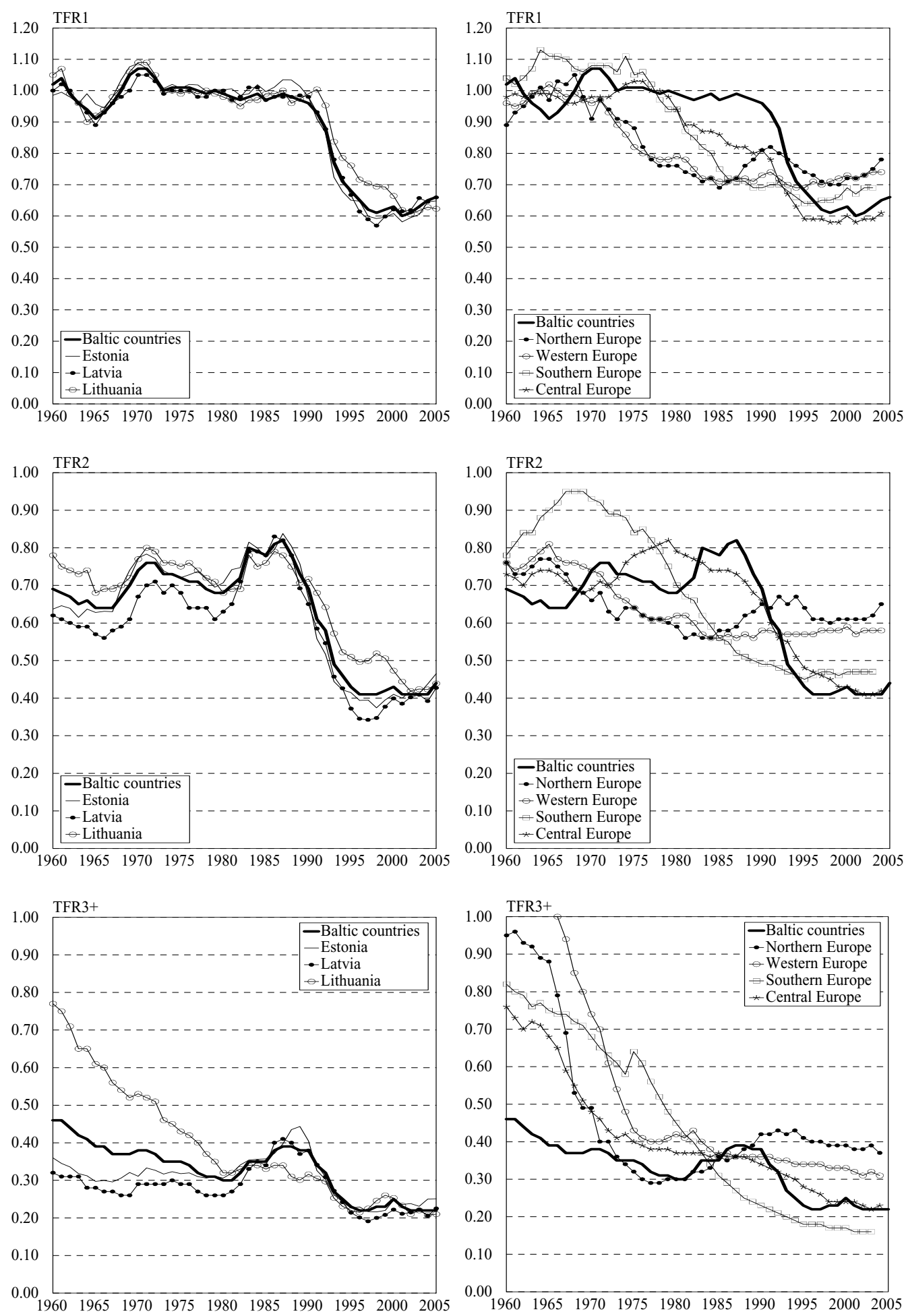

Figure 2. Order-specific total fertility rate 1960-2005. 
In the European context, the repositioning of the Baltic countries in terms of secondorder total fertility rate follows the general pattern observed for all parities combined but the contrast vis-vis other regions becomes even more clear-cut: the Baltic countries featured the lowest level of TFR2 in the 1960s, then moved to the top position by the early 1980 s, stayed there for nearly a decade, and dropped to the bottom once again by the mid-1990s.

Compared to lower parities, the decrease in third+ order total fertility rate in the $1990 \mathrm{~s}$ appears less pronounced, particularly when leaving aside the temporary rise in the second half of the 1980s. The data reveal that the referred increase (up to 0.40) was experienced by Estonia and Latvia. In these countries, total fertility rate for third births had been relatively stable throughout the earlier decades, and in the context of these longer trends, the 1990s did not bring a dramatic reduction in third+ order fertility. In Lithuania, on the other hand, the decrease in the 1990s was preceded by a long-term decline in third+ order fertility. From the beginning of the 1960 s to the early $1980 \mathrm{~s}$ TFR3+ decreased from around 0.80 down to the level of 0.30 . Also, in Lithuania the third + order total fertility rate featured no marked increase in the 1980s, and unlike in Estonia and Latvia, the decrease in TFR3 + in the 1990s could be regarded as a tail end of a long-term downward trend that was temporarily halted in the Eighties. In the recent decade and a half, the TFR3+ has featured fairly similar levels in all three countries.

In comparative perspective, the Baltic countries have stood out for their remarkably low level of third+ order fertility for the 1950s and 1960s. In the early 1960s, the Baltic TFR3 + was more than twice lower than in Western Europe (region featuring the highest level at that time), with Estonia and Latvia having the level nearly three times lower. This situation persisted until the 1970s, and leaving aside Lithuania, this position would have continued up to the early 1980s. Like for first and second births, the Baltic countries changed their lowest position for third births for the highest in the 1980s but this top position was held for a very short period - only a couple of years in the late 1980s. On the other hand, it is important to note that the decrease that followed in the 1990s never brought the indicator back to the lowest level in Europe. In Southern Europe, the TFR3+ has been systematically lower compared to the Baltic region and in the recent years, also Central Europe has featured a slightly lower level of third + fertility.

\section{Timing of childbearing}

A salient feature of the change in fertility patterns in the 1990 s relates to the timing of childbearing. The age at which men and women enter parenthood has lasting implications on their life course and interplay with other careers. From the viewpoint of fertility measurement, the shifts towards earlier or later childbearing have significant consequences on period fertility indicators. 
Figure 3 summarises the trend in the timing of childbearing by means of the mean age of women at first birth. As regards to the Baltic region, the figure reveals a turning point in the trend in the first half 1990s. In these years, the mean age at first birth turned to a steady increase that has persisted until today. Over the recent decade, the ageing of fertility has gained considerable momentum, with the mean age at motherhood shifting upwards about 0.25 years per annum. Despite relatively swift postponement, however, among the regions considered in the article, currently the Baltic countries form an area with the earliest entry into parenthood. However, at the same time the figure also points to the fact that the reasons underlying the observed position of Estonia, Latvia and Lithuania should not be sought from the recent period but rather from earlier developments.
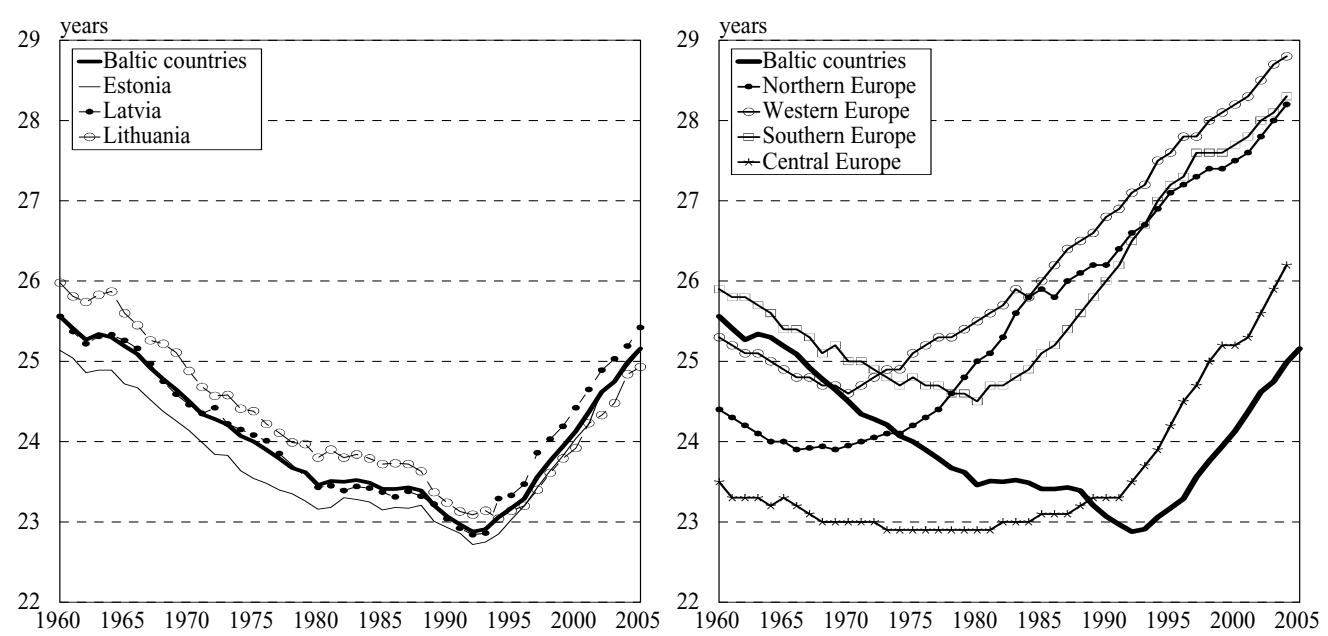

Figure 3. Mean age of women at first births 1960-2005.

As elsewhere in the areas west of Hajnal line, the postwar decades introduced a break in demographic patterns that had prevailed for about two centuries (Hajnal 1965). With respect to timing, the disappearance of the European marriage pattern was accompanied by a marked shift of all reproductive events, including sexual initiation, marriage and childbearing, towards younger ages. This shift shaped the trend in fertility timing all over the realm of European marriage pattern. Figure 3 suggests that in comparative perspective the Baltic countries featured a relatively late entry into motherhood in the immediate postwar decades. In 1960, the mean age of women at first birth ranged from 25.1 years in Estonia to 26 years in Lithuania.

The persistence of late motherhood observed in the Baltic countries in the early postwar decades may be hypothesised to share a common root - societal discontinuity - with the absence of baby boom noted in the previous section. Among others, this conjecture is supported by the cohort data from Estonia that indicate a temporary reversal of the juvenation trend in the timing of motherhood. Among native population, the shift 
towards earlier motherhood temporarily stopped in the 1917 birth cohort and moved upwards for another 7-8 years, until the 1925 birth cohort. Moreover, it was not until women born in 1929 that the mean age at first birth dropped below the level achieved by the 1917 cohort. It seems that precisely this discontinuity accounts for the higher age at childbearing among Estonian women in the 1950s and 1960s, compared to their counterparts in Northern Europe.

Unlike other nations that had experienced the European marriage pattern, the trend towards earlier entry into motherhood persisted noticeably longer in the Baltic countries. It was not until the 1980s that the decline in the age at first (as well as subsequent) birth stopped. In a comparative perspective, the turnaround of the trend and the return of postponement in the West - starting from Northern Europe in the late 1960s, followed by Western Europe in the early 1970s and Southern Europe around 1980 - led to a rapidly growing divergence between the former regions and the Baltic countries. On the other hand, prolonged advancement of childbearing in Estonia, Latvia and Lithuania implied an increasing similarity with the countries of Central Europe under state socialism.

In the early 1990s, the scale of divergence the timing of fertility, along with related features, led some scholars to conteptualise the situation as the appearance of a new "East-West" divide in fertility and family behaviour (Monnier and Rychtarchikova 1992; Roussel 1994). Apart from the historical delineation, the new cleavage was thought to follow the boundaries that separated state socialist regimes from the rest of Europe. Among the factors that upheld and encouraged relatively early family formation until the "meltdown" of the Iron Curtain, the researchers have pointed to various institutional mechanisms, in particular the system of housing allocation (Ni Brolchain 1993; Frejka and Sardon 2004). In the socialist system, the housing market did not exist and new dwellings were distributed according to certain administrative procedures. The impact of this system on family formation and fertility resulted from the point that, as a rule, to become eligible a couple was expected to be in a registered marriage and have housing conditions, in particular a per capita floor space, below a certain standard. The birth of a child helped young couples to increase their chances to move up in the housing queue which was virtually the only possibility to obtain a dwelling in urban areas. It is interesting to note that under market economy the same goal required exactly the opposite strategy - investment in education and career, accompanied with the postponement of childbearing.

The persistence of the old mechanisms in the Baltic region until 1991-92 helps to understand why the turn to postponement emerged so late. By the same token, these mechanisms probably offers a clue why the differentials in the timing of childbearing within the Baltic region have been more limited, compared to other features of fertility development addressed in this article. The left-hand panel of Figure 3 shows that during the advancement of childbearing, among the three countries the mean of age 
at first birth appeared persistently lowest in Estonia and highest in Lithuania, with Latvia placed between its neighbours. The mean age of women at first birth bottomed in Estonia and Latvia in 1992, at 22.7 and 22.8 years respectively. In Lithuania, the measure reached the minimum of 23.0 years two years later (1994).

As regards the recent decade, it is important to note that the turn to postponement has also brought along a change in the order of the countries. Although the differences are relatively small, for most years since 1995 Lithuania has featured a slightly earlier entry into motherhood compared to Latvia and Estonia. Regarding the latter two countries, the first births occur somewhat later in Latvia, just as it was in the earlier decades. Perhaps the varying momentum of fertility ageing across countries is revealed better by the change following the low point in the first half 1990s - by 2005 the increase in the mean age at first birth amounts to 2.6 years in Latvia, 2.4 years in Estonian and 1.8 years in Lithuania. In a comparative perspective, there is still a high potential for further postponement in all three countries. According to the recent statistics, the mean age of woman at first birth has exceeded 25 years in all three countries.

It is a well known demographic fact that in the situation where the age-specific fertility schedules are moving toward older age, this shift depresses the total fertility rate to a lower level than it would reach in the absence of such shift. From a scholarly point of view the parallelism of the postponement and decrease in fertility raises a question to what extent the fall in the period TFR, discussed earlier in the article, was driven by the change in the timing and to what extent it reflected real reduction in the quantum of fertility.

To address the issue, the article applies the adjustment method originally proposed by Bongaarts and Feeney $(1998 ; 2006)$. The results of the calculation for the Baltic countries are provided in Figure 4. A brief glance at the figure is enough to show that the adjusted TFR provides much less dramatic account of period fertility levels than its non-adjusted counterpart. ${ }^{2}$ Although the levels vary between individual countries, the dynamics of two measures of total fertility follows a similar pattern, and in general, in all three countries the data reveal two distinct periods since 1990.

The first sub-period in the early 1990s was dominated by a sharp decrease of the period TFR. In these years, the adjusted total fertility rate was lower than the observed measure which is characteristic of situations where fertility schedule is shifting towards a younger age. In a broader framework, of course, the referred final shift towards earlier motherhood at the turn of the 1990s represents a tail end of a longer trend that followed the disappearance of the European marriage pattern in the region. The calculations performed for earlier periods show the adjusted TFR being lower than the observed measure throughout the period of fertility juvenation.

\footnotetext{
${ }^{2}$ To reduce the impact of random fluctuations, the tempo-adjusted TFRs presented in the figure have been smoothed by moving average.
} 

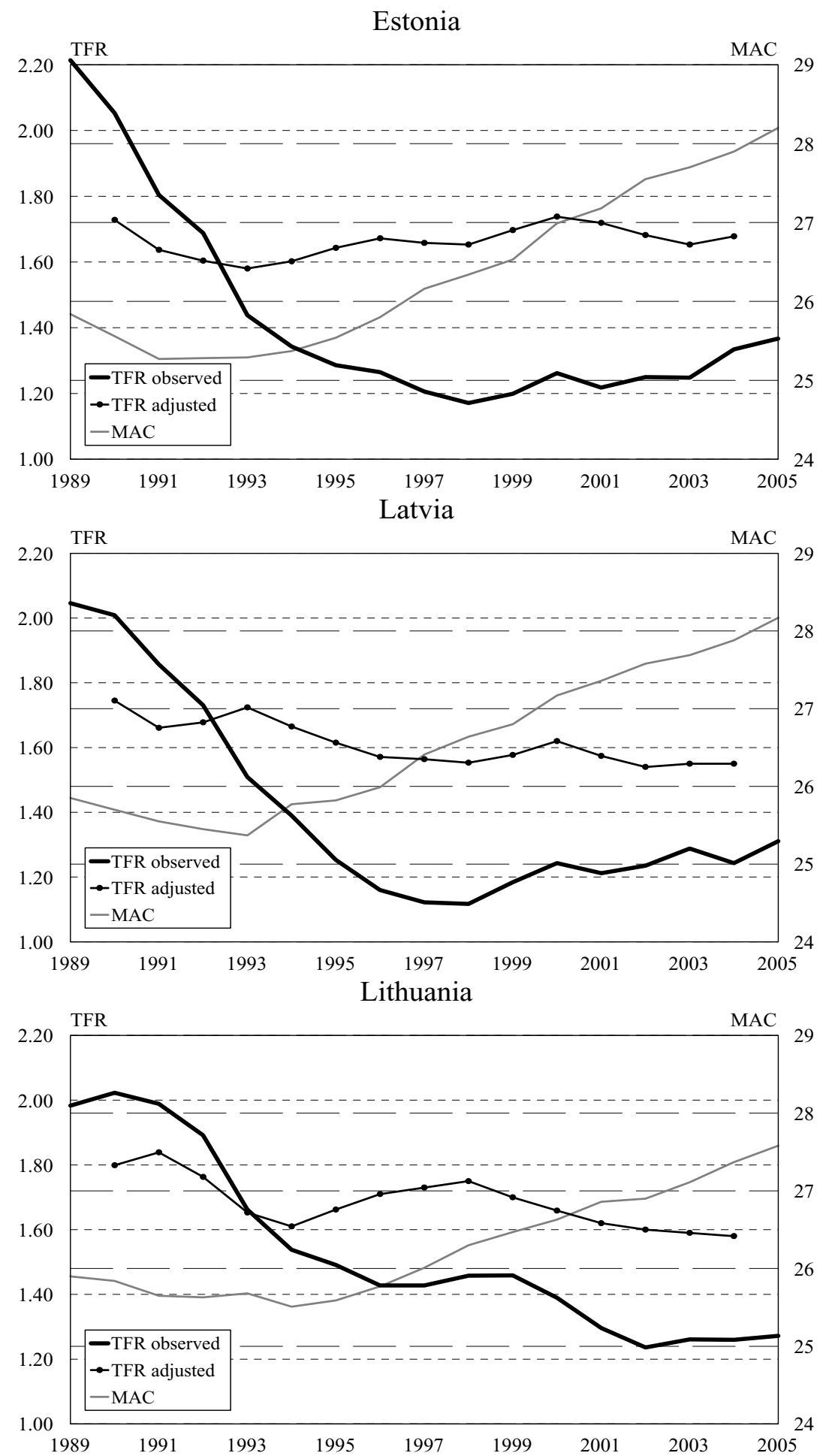

Figure 4. Tempo-adjusted total fertility rate1989-2005. 
From the viewpoint of fertility level, the observation from Figure 4 suggests that until 1992-1993 there is no postponement effect in the Baltic countries. From that point on, the postponement effect emerges as a major factor of observed fertility levels in the Baltic region. This assertion is quantified by the dynamics of the adjusted TFR that stops to decrease, and except for some fluctuations, tends to stabilise at the levels 1.6-1.7, depending on the country. In other words, the drop of the observed TFR well below the referred level since 1992-1993 appears to have been largely driven by the postponement of motherhood. The gap between the observed and adjusted total fertility rates suggests that on average, the change in timing pushes the observed period TFR downwards by 0.3-0.4 units. Put in another way, the timing effect accounts for approximately half of the fertility decrease that occurred in the Baltic countries in the 1990s.

It should be noted that the adjusted measures do not provide a straightforward prediction of the level to which the period fertility will return once the postponement approaches its completion. The main reason for such reservation stems from the uncertainty related to fertility recuperation in the cohorts who are currently postponing their childbearing towards ever higher ages. The recuperation depends on the extent to which women in their early and mid-20s will have their births, foregone in early of stages reproductive career, at a later age. And as anything in the future, the completeness of such recuperation cannot be taken for granted, and obviously, future fertility trend cannot be assumed to necessarily follow a similar path in all three countries.

\section{Age-pattern of childbearing}

A more general account of the recent change in fertility timing is presented by means of age curves for 1989-2005. Up to the early 1990s, the data reveal indeed a very youthful pattern of childbearing. In all three countries, fertility was strongly concentrated into young adulthood, with more than two fifths of all children born between age 20 and 24. Consistent with the observation based on total fertility rates, there seems to be no clear-cut postponement effect during the first half of the 1990s but a decline in fertility prevailing at almost all ages. A minor exception to the general trend was teenage women who sustained a moderate increase in age-specific fertility rates up to 1990-1991 in Estonia and Latvia, and until 1992 in Lithuania. However, the referred rise in teenage motherhood should not be taken as a token of societal disintegration at the onset of societal transition. In a broader timeframe, it rather represents an end of a long rise in teenage childbearing, and at the same time points out some non-synchronism in switching to new behavioural patterns. In effect, precisely this non-synchronism underlies the decrease in the mean age of childbearing in the beginning of the 1990s discussed in the previous section. 

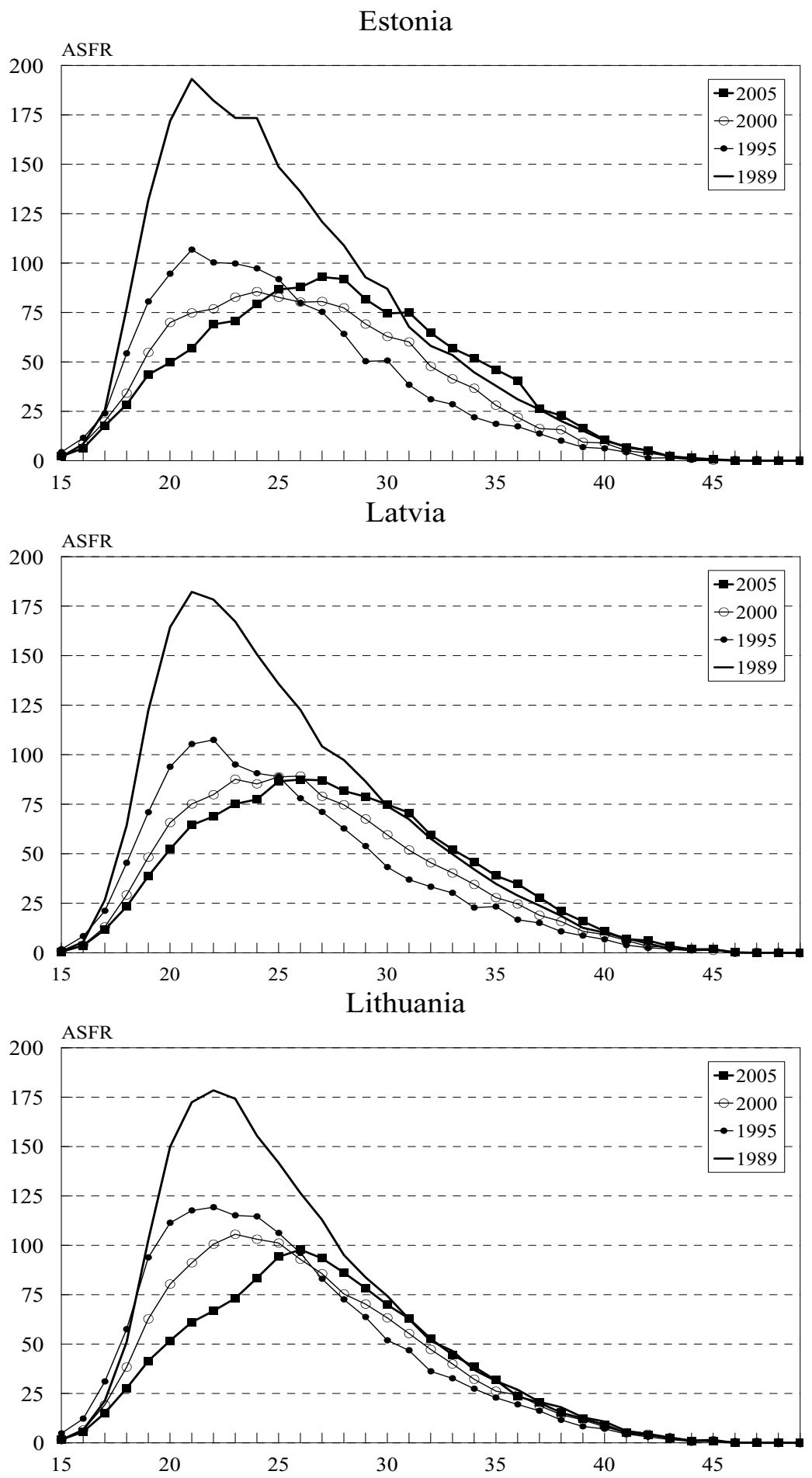

Figure 5. Age-curves of fertility 1989-2005. 
The transformation of age curves between 1995 and 2000 leaves little doubt about the ongoing postponement of childbearing although during that period, in none of the three countries the decrease of fertility rates among younger women was yet offset by the increase in older age groups. This new situation emerges from the comparison of the 2000 and 2005 curves, however, it is manifested to a varying degree in different countries. The postponement has advanced furthest in Estonia where the rise of childbearing after age 25 has fully compensated for the concurrent reduction in younger ages. Also, among Estonian women above 30, the age-specific fertility rates from 2005 clearly exceeded those observed in the late 1980s. Lithuania, at the other end of the spectrum, has featured a slower progress, with the decrease in younger ages dominating the change in 2000-2005 and fertility rates among older women still on a par with the 1989 levels.

From another angle, a varying pace of fertility postponement is corroborated by the year at which women aged 25-29 outnumbered the 20-24 age group in terms of their contribution to total fertility - in Estonia and Latvia the cross-over occurred in 2000 whereas it took until 2003 for Lithuania to reach the same point. In Estonia, by 2005 also the 30-34-year-olds featured a greater input to total fertility than the 20-24 age group. A more refined analysis of postponement by birth order, not presented in the article, relates the above country specificity to varying progression to the second and third parity. Notwithstanding the reasons, however, the shift towards further postponement seems to be firmly under way in all three countries and yet far from the saturation point.

\section{Expansion of non-marital childbearing}

A major aspect of the development of fertility patterns in the Baltic countries pertains to the connection between childbearing and marriage. In the present section non-marital childbearing is analysed by means of the general proportion of children born out of wedlock. Although this measure tends to be analytically inferior to more refined indicators such as non-marital fertility rates, much of its limitations are offset by the wide availability over time and space. In a broader context of family formation, the proportion of non-marital births measures the extent to which childbearing occurs outside registered marriage. However, it is important to note that usually the advancement of this process does not imply an equivalent increase in lone parenthood but is associated with a parallel transformation in family forms, in particular with the spread of cohabitation (Corijn and Klijzing 2001; Macura and Klijzing 1997; Sobotka 2004; Sobotka and Toulemon 2008).

Figure 6 draws attention to the spectacular growth in the proportion of children born to unwed mothers in the Baltic countries. The period since the beginning of the 1990s marked an expansion of out-of-wedlock childbearing, and considering the region as a whole, a persistent upward surge, with no backsliding, has continued for a decade 
and a half. The shift towards increased non-marital childbearing appears particularly strong in comparative perspective, against the background of other regions of Europe. In particular, as the upward slope of the curve strengthened, the figure reveals how the trendline of the Baltic countries broke away from that for Western and Central Europe. In a matter of a decade, it closed most of the gap with Nordic countries which are known as the European vanguard in this regard. In the recent years for which the data are available, the difference in the average proportion of non-marital births has dropped to some five percentage points between the Baltic and Nordic countries. However, it should be noted that with respect to marital/non-marital distinction, the differences among the Baltic countries are larger than for any other aspect of fertility development.
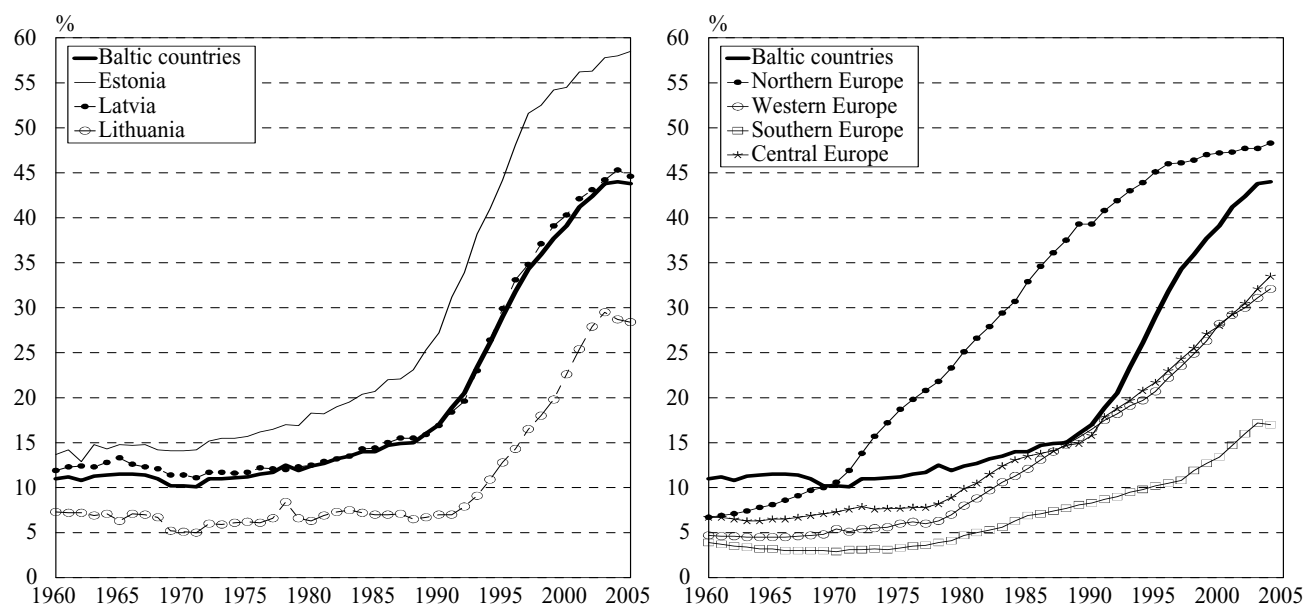

Figure 6. Proportion of non-marital births 1960-2005`.

The exploration of longer trends shows that in the Baltic region the relatively high incidence of births to unwed women is definitely not a new phenomenon that came into being during the recent societal transformation. In the postwar decades, until the end of 1960s, the Baltic countries surpassed all major regions of Europe with respect to the proportion of children born to unmarried mothers. In all three Baltic countries particularly high levels of non-marital fertility were observed in the immediate postwar decade and relate directly to repression and societal discontinuity (Katus 2003; Frejka and Sardon 2004). The return of more normal conditions after Stalin's death implied a decline and temporary stabilisation in the proportion of out-of-wedlock births in the 1960s. For the Baltic region as a whole, the proportion reached the bottom at the turn of the 1970s, followed by a new upward trend that accelerated with each next decade. To this point it is interesting to note that even in its lowest point, the average proportion of non-marital births persistently in the Baltic region exceeded that in Western and Central Europe, let alone the countries of Southern Europe. 
The left-hand panel of Figure 6 indicates that the average proportion of non-marital birth in the Baltic region embeds remarkable diversity across countries. Countrywise the ensuing upsurge in the share out-of-wedlock births began from markedly different levels and progressed at apparently dissimilar rate. In 1989, slightly more than a quarter of children were born to unmarried women in Estonia whereas in Lithuania the corresponding ratio amounted to 7 percent. Latvia was positioned in the middle between these two extremes, with the trendline closely following the average of the three countries. Although the diversity in the proportion of out-of-wedlock births constitutes a persistent feature, the referred difference at the turn of the 1990s mirrored the developments in the 1970s and particularly in the 1980s - in Estonia and Latvia the trends turned to rise in that period whereas in Lithuania a stable level was maintained.

Since 1990 the biggest growth is documented in Estonia where the proportion of children born to unmarried mothers rose by 33 percentage points and reached a remarkable 58.5 percent in 2005 . It must be noted that to an important extent the referred growth reflects a spread of non-marital childbearing into the foreign-origin population which featured persistently low levels of non-marital childbearing until the late 1980s (Katus, Puur and Sakkeus 2002). According to the statistics reported in the Council of Europe demographic yearbook, with its proportion of non-marital births Estonia ranks second after Iceland in recent years (Council of Europe 2006). It is interesting to note that together with Norway and Sweden, only in the referred countries non-marital births constitute a majority among all births. Probably, these populations have come rather close to a point after which hardly any further increase can be expected - among others, this is suggested by the gradually decreasing slope towards the tail end of the curves.

Coming back to the Baltic region, in Latvia the increase amounted to 29 percentage points since 1990 and took the proportion of non-marital births to the level of 45.3 percent. With reference to Northern Europe, this level is comparable to Denmark but exceeds Finland. In Lithuania, on the other hand, the expansion of non-marital childbearing has been less extensive, and combined with a relatively low starting level, the proportion of out-of-wedlock births has not exceeded 30 percent. Against the background of major regions of Europe, in terms of non-marital childbearing Lithuania resembles the situation in the countries of Central Europe.

As mentioned earlier in the section, the rise in out-of-wedlock childbearing indicates a change in the form of conjugal unions rather than the spread of lone motherhood. With respect to the Baltic countries, this assertion is corroborated by recent analyses of union formation, based on national surveys carried out in the framework of the European FFS programme (Katus et al. 2007). Among others, the analysis revealed that among the native populations of Estonia and Latvia, the shift from (direct) marriage to cohabitation, as a prevailing mode of union formation, started well before the fall 
of the Soviet regime, in the birth cohorts of the 1940s, and followed a trajectory rather similar to Nordic countries. A further evidence showing the driving role of nuptiality behaviour in the spread of non-marital childbearing can be drawn from the partnership status of women at first birth.

The results published elsewhere indicate that in Estonia - the Baltic country where the change in the connection between childbearing and marriage is the most advanced the observed upward surge in the proportion of non-marital births was almost entirely carried by cohabiting couples, for the past five decades single mothers have accounted for no more than 10 percent across birth cohorts (Katus, Puur and Põldma 2002). The same analysis revealed that from the life course perspective, among the native population of Estonia the increase in the proportion of non-marital births was generated primarily by the change in the timing of marriage relative to childbearing.

\section{Concluding remarks}

In Estonia, Latvia and Lithuania, the period total fertility rate decreased sharply in the 1990s, and compared to many countries in Central and Eastern Europe, the downward trend has been more pronounced in the Baltic region. However, the analysis revealed that for several reasons the extent of fertility decrease has tended to be overstated.

First, these circumstances relate to the specific features of post-transitional fertility development that differentiate the Baltic countries, particularly Estonia and Latvia, from the patterns observed in other regions of Europe. In the postwar decades, the Baltic region has been characterised by a noticeable stability of fertility levels over the longer run. Being among the lowest in Europe and in the world in the 1950s, Estonian and Latvian period fertility somewhat increased rather than decreased for the period up to the end of 1980s. In such view, it was primarily the high level in the latter period rather than the low level to which fertility dropped in the 1990s that boosted the scale of fertility decline in the region.

Second, concerning the period fertility in the 1990s, the decrease has been strengthened by parallel shifts in the timing of childbearing. In the beginning of the 1990s, the Baltic countries experienced a turn towards the postponement of parenthood which is known to depress the observed period fertility to a lower level than they would otherwise reach in the absence of such shift. The adjustment of total fertility rates shows that the change in the tempo of childbearing accounts for approximately half of the decrease that has occurred in total fertility rate. Moreover, the analysis drew attention to the opposite impact of the timing during the previous decades when the continuous advancement of childbearing pushed fertility levels persistently upward thus strengthening the contrast between the earlier and current fertility levels from another end. In a broader framework, the changing influence of timing evidently calls for a more systematic consideration of its role in the analysis of post-transitional fertility 
development. In particular, the consideration of timing should be extended beyond the stage of postponement, to the early postwar decades that followed the disappearance of the European marriage pattern.

Finally, overstatement of the recent fertility decline was revealed also by the examination of order-specific fertility, particularly with respect to first births. As noted earlier in the article, Baltic countries featured a very high first-order total fertility rate up to the early 1990s. For several years, TFR1 even exceeded the level of 1.0. Understandably, such a situation cannot be assumed to be plausible (or even possible) in cohort perspective. In many other countries, it has been explained by the change of fertility timing, however, in the Baltic countries very high first order total fertility rates prevailed for a remarkably long period of nearly fifty years. This unrealistically high level was sustained even after converting the period fertility rates to cohort rates (Freijka and Sardon 2004). This phenomenon should be explained, in addition to prolonged juvenation of childbearing, by a specific profile of migration in the Baltic region very high migration turnover, and the strong dominance of young single persons in the inflow to the region ${ }^{3}$. Most of these young immigrants returned or moved on one time or another, and in that case, the births that occurred in the meantime remained in the birth registers of the Baltic countries although the population which generated them did not. Moreover, a recent study from Estonia has revealed a considerable number of birth records in which neither father nor mother belonged to civilian resident population of the country, i.e. working for the Soviet military they were not included in the denominator of fertility rates (Katus, Puur and Põldma 2004).

Another interesting feature to be discussed relates to the distinction between marital and non-marital fertility. Among various aspects of the process analysed in the article, non-marital fertility reveals the strongest differentiation between the Baltic countries in the past decades. In broader comparative studies, this aspect is often given secondary importance or even neglected. However, when the purpose is to understand fertility differentials within the Baltic region, this aspect deserves careful attention.

Although gradually weakening since 1990, Lithuania has featured a more traditional connection between childbearing and marriage throughout the postwar decades. As a consequence, the proportion of children born outside wedlock has been systematically lower. In a broader view, the pattern of non-marital fertility in Lithuania resembles the situation in the countries of Central Europe, for example Poland and the Czech Republic. On the other hand, Estonia and to somewhat lesser extent Latvia, belongs to the group of trendsetter countries with respect to non-married cohabitation and non-marital childbearing, along with Sweden, Denmark and Iceland. In other words, with respect to non-marital childbearing two rather distinct patterns are represented within the relatively small Baltic region.

\footnotetext{
${ }^{3}$ For example, in case of Estonia 1947-1991, migration turnover exceeded the total population more
} than twofold (Sakkeus 2003). 
How can one then explain these divergent features? Most importantly, the exploration of longer demographic trends reveals that noticeable differences in fertility patterns between Estonia, Latvia and Lithuania do not constitute a short-term feature. On the contrary, these differences are persistent and stretch back to the onset of demographic transition in the region in the late 19th century. Over that period, innovative behavioural patterns - starting from the parity-specific family limitation - have emerged earlier in Estonia and Latvia, and followed by Lithuania with a certain time-lag. This time-lag could be expressed also with respect to the spread of cohabitation and non-marital childbearing. In Estonia, these features of the second demographic transition started to emerge in the 1960s whereas in Lithuania no similar change occurred until the 1990s.

A deep-rooted historical legacy may also underlie the intermediate position of Latvia between Estonia and Lithuania that emerged recurrently in the article. This position can be regarded as a result of the division of Latvia, stretching back for several centuries. Among others, this division represents a conspicious religious and cultural divide that emerged in the 17 th century when the northern and western parts of Latvia became Lutheran with the southern and eastern parts remaining in the domain of Catholicism. As a result, the western and northern parts of the country feature patterns that are similar to Estonia whereas the southern and eastern parts have shared noticeable similarity with developments in Lithuania.

In case the hypothesis about the role of path dependency in demographic development holds, the differences involving the Baltic region are likely to persist. With respect to fertility levels, the data for the very recent years reveal a re-emerging difference in the region. In Estonia, the observed total fertility rate is expected to exceed 1.70 in 2008, with the postponement of childbearing still well under way. Although fertility increase can be discerned also in Lithuania, its scale appears noticeably smaller and resembles its southern neighbours. Only the future will provide a definitive answer but considering the long-term demographic development of the Baltic countries, a more pronounced recuperation of fertility levels in Estonia, and to somewhat lesser extent in Latvia should not be a major surprise. Among others, this is closely in line with the prediction of Lesthaeghe and Surkyn with reference to the Central and Eastern Europe (2002). They noted the possibility that those countries with the faster rate of transition in household structures [i.e. the spread of new family forms] will be the first to move to fertility recuperation, and hence to be the first to recover to more acceptable levels of subreplacement fertility. The evidence presented in this article for indicate that the latter assertion is becoming a fact of life in the Baltic region. 


\section{Acknowledgments}

The article has been prepared in the framework of research theme $0132703 \mathrm{~s} 05$ by the Estonian Ministry of Education and Science and benefited from the support of the Estonian Science Foundation (grant no. 7619). The authors are grateful to Uldis Usackis and Danguole Svidleriene for providing statistics on the recent fertility developments in Latvia and Lithuania.

\section{Appendix. Data sources used in the calculation of fertility rates}

\begin{tabular}{|l|c|c|}
\hline Country & $\begin{array}{c}\text { Live births by age of mother (single-year } \\
\text { age groups) and parity (1,2 and } 3+)\end{array}$ & $\begin{array}{c}\text { Mid-year female population } \\
\text { by single-year age groups }\end{array}$ \\
\hline Estonia & $\begin{array}{c}\text { Unpublished tabulations } \\
\text { from Statistical Office of Estonia }\end{array}$ & Estonian Population Databank (EKDK) \\
\hline Latvia & $\begin{array}{c}\text { Unpublished tabulations } \\
\text { from Statistical Office of Latvia }\end{array}$ & $\begin{array}{c}\text { Published and unpublished tabulations } \\
\text { from Statistical Office of Latvia }\end{array}$ \\
\hline Lithuania & $\begin{array}{c}\text { Unpublished tabulations } \\
\text { from Statistical Office of Lithuania }\end{array}$ & $\begin{array}{c}\text { Published and unpublished tabulations } \\
\text { from Statistical Office of Lithuania }\end{array}$ \\
\hline
\end{tabular}

Note: Parity refers to biological order of birth; age of mother refers to completed at the time of childbirth.

\section{References}

Bongaarts, John and Griffith Feeney 1998. On the Quantum and Tempo of Fertility. Population and Development Review 24(2): 271-291.

Bongaarts, John and Griffith Feeney 2006. The Quantum and Tempo of Life-Cycle Events. Vienna Yearbook of Population Research 2006: 115-151.

Calot, Gerard and Jean-Paul Sardon. 1997. Etonnante fecondite suedoise. Futuribles 217:5-14.

Coale, Ansley, Barbara Anderson and Erna Härm. 1979. Human Fertility in Russia Since the Nineteenth Century. Princeton: Princeton University Press.

Coale, Ansley and Susan Watkins .1986 (Eds). The Decline of Fertility in Europe. Princeton, Princeton University Press.

Coleman, David. 1996 (Ed). Europe's Population in the 1990s. New York: Oxford University Press.

Corijn, Martine and Erik Klijzing. 2001. (Eds). Transition to Adulthood in Europe. Dordrect: Kluwer Academic Publishers.

Council of Europe .2006. Recent Demographic Developments in Europe 2005. Strasbourg: Council of Europe Publishing. 
Dorbritz, Jörg and Dimiter Philipov. 2003. Demographic Consequencies of the Transition in the Countries of Central and Eastern Europe. Strasbourg: Council of Europe Publishing.

Eurostat. 2008. Theme: Population and Social Conditions. Available at ec.europa.eu/eurostat/, last accessed on 5 October 2008.

Festy, Partick. 1984. Fertility in Western Countries 1870 to 1970. Bankok: United Nations.

Frejka, Tomas and Jean-Paul Sardon. 2004 (Eds). Childbearing Trends and Prospects in Low Fertility Countries. A Cohort Analysis. Dordrecht: Kluwer Academic Publishers. Frejka, Tomas and Tomas Sobotka (2008). Overview Chapter 1: Fertility in Europe: Diverse, delayed and below replacement. Demographic Research, Special Collection 7: Childbearing Trends and Policies in Europe, Vol.19, article 3, pp. 15-46.

http:/www.demographic-research.org/Volumes /Vol19/3/.

Golini, Antonio. 1998. How Low Can Fertility Be? An Empirical Exploration Population and Development Review (1): 59-73.

Hajnal, John. 1965. European Marriage Patterns in Perspective. In: Population in History. Essays in Historical Demography, edited by D.Glass and D. Eversley, 101-143. London: Edward Arnold.

Katus, Kalev. 1994. Fertility Transition in Estonia, Latvia and Lithuania. In: Demographic Trends and Patterns in the Soviet Union Before 1991, edited by W. Lutz, S. Scherbov and A. Volkov, pp 89-111. London-New York: Routledge.

Katus, Kalev. 1997. Long-term Fertility Development in Baltoscandia. Yearbook of Population Research in Finland (34): 18-35.

Katus, Kalev. 2000. General Patterns of Post-transitional Fertility in Estonia. Trames 4(3) (Special Issue on Estonian Population), pp. 213-230.

Katus, Kalev. 2003. Non-marital Fertility in the Baltic Region. In: Unity and Diversity of Population Development: Baltic and South Caucasian Regions, edited by Kalev Katus and Allan Puur, pp. 207-224. Tallinn: EKDK.

Katus, Kalev and Allan Puur. 2003 (Eds). Unity and Diversity of Population Development: Baltic and South Caucasian Regions. Tallinn: EKDK.

Katus, Kalev and Allan Puur. 2006 (Eds). Eesti rahvastikuarengu raamat. [Population Development in Estonia]. RU Series D, no.5. Tallinn: EKDK.

Katus, Kalev, Allan Puur and Asta Põldma. 2002. Eesti põlvkondlik rahvastikuareng. [Cohort Population Development in Estonia]. RU Series D, no.2. Tallinn, EKDK. Katus, Kalev, Allan Puur and Asta Põldma. 2004. Eesti sünniandmestik 1944-1959: teostuvusuuring ja kvaliteedianalü̈̈s. [Estonian Birth Records 1944-1959: Feasibility Study and Quality Analysis]RU Series A, no.42. Tallinn: EKDK.

Katus, Kalev, Allan Puur, Asta Põldma and Luule Sakkeus. 2007. First Union Formation in Estonia, Latvia and Lithuania: Patterns across Countries and Gender. Demographic Research, vol.17, article 10, pp.247-300, http://www. demographic-research.org/Volumes/ Vol17/10/.

Katus, Kalev, Allan Puur and Luule Sakkeus. 2000. Fertility and Family Surveys in Countries of the ECE Region. Standard Country Report. Estonia. New York and Geneva: United Nations. 
Katus, Kalev, Allan Puur and Luule Sakkeus. 2002. Immigrant Population in Estonia. In: The Demographic Characteristics of Immigrant Populations, edited by W. Haug, P. Compton and Y. Courbage, pp.131-92. Strasbourg: Council of Europe Publishers.

Katus, Kalev, Allan Puur and Luule Sakkeus. 2008. Family Formation in the Baltic Countries: A Transformation in the Legacy of State Socialism. Journal of Baltic Studies 39(2): 123-56.

Kohler, Hans-Peter and I. Kohler. 1999. Fertility Decline in Russia: Social versus Economic Factors. Paper to the EAPS European Population Conference, the Hague, 1999.

Kohler, Hans-Peter and Jose Ortega. 2002. Tempo-adjusted Period Parity Progression Measures, Fertility Postponement and Completed Cohort Fertility. Demographic Research 6(6): 92-144.

Kohler, Hans-Peter, Francesco Billari and Jose Ortega. 2002. The Emergence of LowestLow Fertility in Europe. Population and Development Review 28(4): 641-680.

Kucera, T, Olga Kucerova, Oksana Opara and Eberhard Schaich. 2000 (Eds). New Demographic Faces of Europe. Berlin, Springer Verlag.

Lesthaeghe, Ron and Dirk van de Kaa. 1986. Twee demografische transities? In: Bevolking: Groei en Krimp, edited by R.Lesthaeghe and D. van de Kaa, pp. 9-24. Deventer: Van Loghum-Slaterus.

Lesthaeghe, Ron and Paul Williams. 1999. Is Low Fertility a Temporary Phenomenon in the European Union. Population and Development Review 25(2): 211-228.

Lesthaeghe, Ron and Johan Surkyn. 2002. New Forms of Household Formation in Central and Eastern Europe: Are They Related to Emerging Value Orientations. Economic Survey of Europe, vol.1, pp.197-216. New York and Geneva: United Nations Economic Commission for Europe.

Macura, Miroslav and Erik Klijzing. 1997. Cohabitation and Extra-marital Childbearing: Early FFS evidence. International Population Conference, vol.2. Liege, IUSSP, pp. 885-902.

Macura, Miroslav and Alphonse MacDonald. 2003. Fertility and Fertility Regulation in Eastern Europe: from the Socialist to the Post-socialist Era. In: Population of Central and Eastern Europe: Challenges and Opportunities, edited by Irena Kotowska and Janina Jozwiak, pp.35-90. Warsaw, EAPS.

Monnier, Alain and Jitka Rychtarchikova. 1992. The division of Europe into East and West. Population: An English Selection, vol.4, pp. 129-160.

Ni Brolchain, Maire. 1993. East-West Marriage Contrasts, Old and New. In: European Population. Demographic Dynamics, edited by A.Blum and J.Rallu, pp.461-479. Paris: John Libbey Eurotext.

Philipov, Dimiter. 2002. Fertility in Times of Discontinuous Societal Change: the Case of Central and Eastern Europe. MPIDR Working Papers, no.24. Rostock: MPIDR.

Roussel, Louis. 1994. Fertility and Family. European Population Conference. Proceedings, vol.1, pp. 35-110. Geneva: United Nations.

Rychtarchikova, Jitka. 2000. Demographic Transition or Demographic Shock in Recent Demographic Development in the Czech Republic. Acta Universitatis Carolinae Geographica 35(1): 89-102. 
Sakkeus, Luule. 2003. Migration Trends in the Baltic States 1945-1991. In: Unity and Diversity of Population Development: Baltic and South Caucasian Regions, edited by Kalev Katus and Allan Puur, pp.253-78. RU Series D, no.3. Tallinn, EKDK.

Sobotka, Tomas. 2004. Postponement of Childbearing and Low Fertility in Europe. Amsterdam: Thela Thesis.

Sobotka, Tomas and Laurent Toulemon. 2008. Changing Family and Partnership Behaviour: Common Trends and Persistent Diversity across Europe. Demographic Research, Special Collection 7: Childbearing Trends and Policies in Europe, Vol.19, article 6, pp.85-138, http://www.demographic-research.org/Volumes/Vol19/6/.

Stankuniene, Vlada. 2000. Demographic Situation in Lithuania. In: New Demographic

Faces of Europe, edited by T. Kucera, O. Kucerova, O. Opara and E. Schaich. Berlin: Springer Verlag.

Stankuniene, Vlada, Mare Baublyte, Vida Kanopiene and Sarmite Mikulioniene. 2000. Fertility and Family Surveys in Countries of the ECE Region. Standard country report. Lithuania. New York and Geneva: United Nations.

Stankuniene, Vlada and Aiva Jasilioniene. 2008. Lithuania: Fertility Decline and Its

Determinants. Demographic Research, Special Collection 7: Childbearing Trends and Policies in Europe, Vol.19, article 20, pp. 705-742,

http://www.demographic-research.org/Volumes/Vol19/20/.

Steshenko, V. 2000. Demographic Situation in Ukraine in the Transition Period. In:

New Demographic Faces of Europe, edited by T. Kucera, O. Kucerova, O. Opara and E. Schaich. Berlin: Springer Verlag.

TsSU Estonii (1975-1987). Estestvennoe dvizhenie i migratsia naselenia Estonskoi SSR. Tallinn.

TsSU Latvii (1965-1989). Estestvennoe dvizhenie i migratsia naselenia Latviskoi SSR. Riga.

TsSU Litvõ (1966-1990). Pokazateli estestvennogo dvizhenia naselenia Litovskoi SSR. Vilnius.

Van de Kaa, Dirk. 1987. The Europe's Second Demographic Transition, Population Bulletin 42(1): 1-59.

Van de Kaa, Dirk. 1999. Europe and its Population: the Long View. In: European Populations. Unity in Diversity, edited by D. van de Kaa, H. Leridon, G. Gesano and M. Okolski, pp. 1-50. Dordrecht: Kluwer Academic Publishers.

Vishnevski, Anatoli. 2006 (ed). Demografitsheskaja modernizatsia Rossii 1900-2000. Moscow, Novoje Izdatelstvo.

Zakharov, Sergei. 2000. Fertility Trends in Russia and the European Newly Independent States: Crises or Turning Point? Special Issue of Population Bulletin 40/41: 292-317.

Zvidrins, Peteris, Ligita Ezera and Aigars Greitans. 1998. Fertility and Family Surveys in Countries of the ECE Region. Standard Country Report. Latvia. New York and Geneva, United Nations.

Zvidrinsh, Peteris. 2000. Demographic Situation in Latvia. In: New Demographic Faces of Europe, edited by T. Kucera, O. Kucerova, O. Opara and E. Schaich. Berlin: Springer Verlag. 